\title{
Resistance training in overweight women on a ketogenic diet conserved lean body mass while reducing body fat
}

\author{
Pal T Jabekk*, Ingvild A Moe ${ }^{1}$, Helge D Meen ${ }^{1}$, Sissel E Tomten ${ }^{3}$, Arne T Høstmark ${ }^{1,2}$
}

\begin{abstract}
Background: The aim of the present study was to compare the effects of 10 weeks resistance training in combination with either a regular diet (Ex) or a low carbohydrate, ketogenic diet (LC+Ex) in overweight women on body weight and body composition.

Methods: 18 untrained women between 20 and 40 years with $\mathrm{BMI} \geq 25 \mathrm{~kg}^{*} \mathrm{~m}^{-2}$ were randomly assigned into the Ex or LC+Ex group. Both groups performed 60-100 min of varied resistance exercise twice weekly. Dietary estimates were based on two 4-day weighed records. Body composition was estimated using Dual Energy X-ray Absorptiometry. Fasting blood samples were analyzed for total-, HDL- and LDL-cholesterol, triacylglycerols, and glucose.

Results: 16 subjects were included in the analyses. Percentage of energy (En\%) from carbohydrates, fat and protein was 6, 66, and 22 respectively in the (LC+Ex) group and 41, 34, 17 in the Ex group. Mean weight change (pre-post) was $-5.6 \pm 2.6 \mathrm{~kg}$ in $L c+E x ;(p<0.001)$ and $0.8 \pm 1.5 \mathrm{~kg}$ in Ex; $(p=0.175)$. The $L c+E x$ group lost $5.6 \pm 2.9 \mathrm{~kg}$ of fat mass $(p=0.001)$ with no significant change in lean body mass $(L B M)$, while the Ex group gained $1.6 \pm 1.8 \mathrm{~kg}$ of LBM ( $p=0.045)$ with no significant change in fat mass $(p=0.059)$. Fasting blood lipids and blood glucose were not significantly affected by the interventions.

Conclusion: Resistance exercise in combination with a ketogenic diet may reduce body fat without significantly changing LBM, while resistance exercise on a regular diet may increase LBM in without significantly affecting fat mass. Fasting blood lipids do not seem to be negatively influenced by the combination of resistance exercise and a low carbohydrate diet.
\end{abstract}

\section{Background}

The prevalence of obesity is increasing and there is a need for safe and effective long term weight loss strategies. Low carbohydrate ketogenic diets have the potential to be one such strategy and recent research supports the notion that these diets may be as effective or more effective than regular calorie restricted diets, both in reducing body weight and in improving metabolic disorders [1-4]. Overweight and obesity are commonly associated with a cluster of metabolic risk factors related to insulin resistance [5]. Carbohydrate restricted diets seem to improve glycemic control and other

\footnotetext{
* Correspondence: jabekk@gmail.com

'Department of Sport Medicine, Norwegian School of Sport Sciences,
} Sognsveien 220, Oslo, Norway features of the metabolic syndrome, and are generally found to beneficially influence risk factors for cardiovascular diseases $[5,6]$.

A 2006 Cochrane meta - analysis [7] concluded that a low carbohydrate diet without an imposed energy restriction, appears to be at least as effective as low fat energy restricted diets in inducing weight loss during time periods up to 1 year. A number of other studies has confirmed this finding [8-11]. A more recent systematic review [4] concluded that low carbohydrate/high protein diets are more effective during a 6 month period and as effective as low-fat diets in reducing weight and cardiovascular disease risk up to 1 year [4]. In contrast, Sacks et al [12] recently observed no difference in weight loss after introducing four diets differing in carbohydrate as well as fat and protein content in a 2 year 
study. However, the dietary goals were only partly achieved and the lowest average intake of carbohydrate was found to exceed $42 \mathrm{En} \%$ both at 6 and 24 months

A greater weight loss with a carbohydrate restricted diet compared to a fat restricted diet has been shown to persist under isocaloric conditions [13]. This finding has been classified as a decreased caloric efficiency or a metabolic advantage [13-15], and may be an additional positive feature of carbohydrate restriction. The mechanisms for a metabolic advantage is thought to be related to the inefficiency of various metabolic cycles and especially protein turnover [13].

An important issue related to the effectiveness of any weight reducing regime is the impact on body composition, thus the effectiveness of different diets may be difficult to compare based on body weight reduction alone. Loss of lean body mass seems to be a common observation in most types of weight loss strategies [16-19]. In one study [20], 8 weeks of regular calorie restricted diet with $54-60 \%$ of energy from carbohydrate, caused a significant decrease in body weight in both men and women. However, the loss of fat mass in the female participants was accompanied by a large loss of LBM and did not cause any significant decrease in the percentage of body fat. There are conflicting results concerning the impact of low carbohydrate diets vs. low fat diets on body composition during weight reduction although several results indicate an advantage of low carbohydrate diets in maintaining or increasing LBM during dieting [21-23]. According to a meta - regression by Krieger et al [14], low carbohydrate diets are associated with a greater total loss of fat free mass, but also greater loss of fat mass and total body weight and thus a greater lowering of body fat percentage, compared with diets higher in carbohydrate.

The most effective tool for increasing or maintaining lean body mass is resistance exercise training [24]. Resistance exercise has been shown to limit the loss of LBM [25-27] during weight loss, although aerobic exercise has been shown to have similar effects [19]. Maintaining or increasing LBM is of importance for maintaining an adequately high metabolism and reduce the tendency to regain weight [25] and for maintaining adequate body function with aging $[28,29]$. In addition, resistance exercise also has the potential to improve metabolic disorders associated with overweight and poor glycemic control [30-32], to reduce the requirement for diabetes medications and to reduce abdominal adiposity and systolic blood pressure [30]. Resistance exercise has also been associated with improvements in cardiovascular disease (CVD) risk factors in the absence of significant weight loss [25].

A comparatively large loss of lean body mass to fat mass has been proposed as a possible explanation for the frequently observed long term failure of various weight loss regimes [33]. As loss of fat may seem to be greater when intake of carbohydrates is restricted compared to fat restriction [9,34-38], and as resistance exercise seems to be the most effective tool for increasing muscle mass, a combination of the two strategies may have the potential for weight loss with a favorable change in body composition.

However, with limited glycogen stores resulting from a carbohydrate restricted diet, physical performance and especially anaerobic performance may be attenuated [39], and little is known of the ability to perform severe fatiguing exercise on a low carbohydrate ketogenic diet. Even less is known of the ability to perform enduring anaerobic exercises like heavy resistance exercise.

The aim of the present study was therefore to investigate how resistance exercise in combination with a low carbohydrate ketogenic diet would influence body weight and composition compared to the same resistance exercise in combination with a regular diet, and if the two regimes might have any effects on fasting blood lipids.

\section{Methods}

\section{Subjects}

Overweight female volunteers were recruited from the Oslo area, through newspaper, webpage and local community notices. Participants were between 20 - 40 years, with a BMI $\geq 25 \mathrm{~kg} / \mathrm{m}^{2}$. The participants had not previously been using low carbohydrate diets, and had not participated in regular resistance exercise during the last 6 months. Exclusion criteria included pregnancy or planned pregnancy, cardiovascular disease, diabetes, kidney diseases, physical disabilities that would hinder resistance exercise or medications that could potentially influence exercise or blood variables. Eighteen subjects fulfilled the criteria and were randomized to either resistance exercise combined with a regular diet (Ex) or resistance exercise in combination with a low carbohydrate ketogenic diet (Lc+Ex).

Prior to the study a written informed consent was obtained from all participants. In addition, all subjects provided a written consent from their personal physician. The study was approved by The Regional Ethics Committee of Norway (ref.nr: S-08251a).

\section{Final study group}

One participant in the Lc+Ex group did not complete the study due to personal reasons. Another participant in the Ex group had reduced her carbohydrate intake to a level that induced ketosis. The dietary records from this participant further supported this finding and revealed a dietary pattern similar to that of the $\mathrm{Lc}+\mathrm{Ex}$ group. As a consequence, data from this participant 
were excluded. Thus, the final analyses included 16 participants.

\section{Exercise intervention}

All exercise was performed at the Norwegian School of Sport Sciences (NSSS) and every exercise session was supervised by at least one qualified instructor. During a pre-session all subjects were instructed in the exercise program. During this session the individual 12 repetition maximum (12 RM) in all exercises was assessed. Eight exercises were performed after an initial low-intensity warm up (10 $\mathrm{min})$ on a cardio machine. The exercises consisted of supine leg press, seated leg extension, seated leg curl, seated chest press, seated rowing, seated shoulder press, seated pull down and standing biceps curl. As far as possible the exercises were conducted in the given order. During the first five weeks of the intervention, all exercises were performed at $12 \mathrm{RM}$ with three sets on leg exercises and one set on upper body exercises. After the initial five weeks, resistance loads were increased to $8 \mathrm{RM}$ and an additional set was added to the upper body exercises. Each exercise included two warm - up sets with a resistance equivalent to approximately $25 \%$ and $50 \%$ of the maximum load (i.e. 12 RM \& 8 RM). Resting periods of approximately $90 \mathrm{~s}$ between all sets were encouraged. All participants were advised not to participate in other forms of resistance exercise during the study period, and to otherwise maintain their usual level of physical activity throughout the study.

\section{Diet intervention}

Participants in both groups were given a daily multivitamin mineral supplement. Each group was counseled in exercise and diet during a single group session. Participants in the Lc+Ex group were given information on the rationale and implementation of the dietary intervention and were given a commercially available book on a low carbohydrate ketogenic diet (Slank med ketolysekuren: en enklere vei til et lettere liv; "Slim with ketolysis: A simpler way to a lighter life") [40] in addition to handouts. The preparation of food was self administered. No restrictions were made regarding energy content, fat and protein content or fatty acid composition. The only restriction was on intake of carbohydrates, and the goal was to restrict carbohydrate intake until ketone bodies were detectable in the urine. The presence of ketone bodies was detected with a semi quantitative method using urine reagent strips (Ketolyse AS). The reagent strips indicated the concentration of acetone and acetoacetic acid in the urine. Participants were told to start the intervention with less than $20 \mathrm{~g}$ carbohydrate per day and to gradually increase the ingestion of carbohydrates at their convenience, as long as they maintained a color change on the urine reagent strips. The diet intervention was thus defined as a carbohydrate restriction that caused positive tests for urinary ketone bodies. Participants were told that they could consume unlimited amounts of meats, fish, eggs, cheeses, margarines, butters and oils. They were further instructed to add low carbohydrate food to their diet as they saw fit.

\section{Body mass and body composition}

Body weight and composition was determined by Dual Energy X - ray Absorptiometry (DEXA) total body scanner (Prodigy Lunar, Scanex Medical Systems A/S). The dexa scanner partitions body mass into three components: fat, lean soft tissue, and bone mineral using two $\mathrm{x}$-rays. Height was measured to the nearest $0.5 \mathrm{~cm}$ using a wall mounted stadiometer.

\section{Blood sampling}

Venous blood samples were drawn in the morning after an overnight fast, at baseline, halfway into the intervention and the week following the intervention period. Carbohydrate restriction was maintained until the last blood sample was collected. Samples were collected at the Norwegian School of Sport Sciences by qualified health personnel, centrifuged and sent to a certified medical laboratory (Fürst Medical Laboratory, Oslo, Norway). Serum blood samples were analyzed for total-, HDL- and LDL-cholesterol, triacylglycerols (TAG), and glucose using automated photometric techniques (Modular P Roche; Roche Diagnostics). The baseline sample was also analyzed for creatinine.

\section{Diet analyses}

The subjects weighed and recorded all their intake of food and drinks on four consecutive days (Wednesday to Saturday) on two occasions, using an electronic weight scale (precision $2 \mathrm{~g}$ ). When special recipes were supplied by the subjects, each ingredient was entered separately. The dietary data were analyzed using the Norwegian Nutritional Computer Analysis Program (Mat på Data v.5) which is based on the Norwegian Food Composition Tables [41]. Mean daily intakes were estimated to be $1 / 4$ of the individual total recorded amounts. The diet recordings were performed during the weeks 4 and 7 of the study. The mean of the two recordings were used as an estimate of dietary intake during the intervention period.

\section{Statistical analyses}

Statistical analyses were performed using SPSS for WINDOWS software (version 14.0; SPSS Inc.). Changes from baseline were assessed using paired sample $t$ - test. Differences in group means were assessed using independent sample $\mathrm{t}$ - test. Correlation analysis was used to determine relations between variables. Statistical 
significance was set at $\mathrm{p} \leq 0.05$. Unless otherwise indicated, values are presented as mean values $\pm \mathrm{SD}$.

\section{Results}

Attendance at the exercise sessions averaged 18 out of 20 sessions and did not differ between groups.

Changes in body weight and body composition (Table 1) At baseline there were significant differences between groups in body weight $(\mathrm{p}=0.04)$ and LBM $(\mathrm{p}=0.014)$. These differences were not significant when corrected for differences in height i.e. BMI (Table 1).

All subjects in the Lc+Ex group lost weight. While the Lc+Ex group in average lost $5.6 \pm 2.6 \mathrm{~kg}$ body mass ( $\mathrm{p}<0.001)$, the Ex group had a non significant increase in body weight $0.8 \pm 1.5 \mathrm{~kg}(\mathrm{p}=0.175)$ (figure 1). Body weight change was significantly different between groups $(\mathrm{p}<0.001)$. The Ex group lost on average $0.6 \mathrm{~kg}$ of fat mass $(\mathrm{p}=0.059)$ from $40.2 \pm 6.3 \mathrm{~kg}$ to $39.5 \pm 6.6 \mathrm{~kg}$ and had a significant increase in LBM $(1.6 \pm 1.8 \mathrm{~kg}, \mathrm{p}=$ $0.045)$. In the Lc+Ex group, mean fat mass was reduced by $5.6 \pm 2.9 \mathrm{~kg}(\mathrm{p}<0.001)$ from $44.0 \pm 8.6 \mathrm{~kg}$ to $38.4 \pm$ $9.1 \mathrm{~kg}$. However, individual fat loss varied greatly (Range: - $2.2 \mathrm{~kg}$ to $-10.5 \mathrm{~kg}$ ).

Mean LBM change in the Lc+Ex group was not significant $(0.1 \pm 1.7 \mathrm{~kg}, \mathrm{p}=0.897)$ and although a significant increase was found within the Ex group, there was no significant difference in LBM change between groups $(\mathrm{p}=0.113)$. The large individual differences in body fat and LBM change are presented in figure 2. Both intervention groups experienced a favorable change in body composition as percent body fat decreased from $47.3 \pm$ 5.8 to $43.7 \pm 7.0 \mathrm{~kg}(\mathrm{p}=0.006)$, in the Lc+Ex group and from $47.9 \pm 3.3$ to $46.7 \pm 4.1 \mathrm{~kg}(\mathrm{p}=0.028)$, in the Ex group.

\section{Dietary nutrient intakes (Table 2)}

The dietary records revealed no significant group difference in the total energy intake $(p=0.264)$. Fat intake was significantly higher $(\mathrm{p} \leq 0.001)$, and carbohydrate was significantly lower in Lc+Ex $(\mathrm{p} \leq 0.001)$. Mean carbohydrate intake in the Lc+Ex group was $23 \mathrm{~g} /$ day, i.e. $5.6 \%$ of the energy intake. This level was sufficiently low to induce ketosis as indicated by the urine reagent strips. Total protein intake (g/day) did not differ between groups $(\mathrm{p}=0.133)$, but did differ significantly expressed as a percentage of total energy $(p=0.007)$.

In the Lc+Ex group there was a significant negative correlation between the reduction in fat mass and dietary fat intake in grams $(r=-0.714, p=0.047)$ and also between the reduction in fat mass and energy intake $(r=-0.810, p=0.015)$. In the Ex group there was a significant correlation between carbohydrate intake in grams and LBM increase $(\mathrm{r}=0.707, \mathrm{p}=0.05)$. Pooled data from the two groups did not show significant correlations between energy intake and reduction in body fat mass $(r=-0.315)$.

\section{Fasting blood lipids and glucose (Table 3)}

Fasting values of blood glucose, total-, HDL- and LDLcholesterol, and triacylglycerols (TAG) did not differ significantly between the groups at baseline. At midpoint and end point, the Lc+Ex had significantly lower fasting TAG levels $(\mathrm{p}=0.033$ and $\mathrm{p}=0.044$ respectively). Neither the combination of low carbohydrate intake and exercise nor exercise with a regular diet had any significant effects on the measured blood variables.

\section{Adverse effects}

Adverse effects related to the two regimes were not observed. One participant in the Lc+Ex group experienced low back pain due to a previous injury when performing the leg press exercise. This participant refrained from this exercise for most of the intervention. Some of the participants experienced stomach discomfort when taking the multi - vitamin mineral supplements on an empty stomach. This was corrected after the participants were encouraged to take the supplements with a meal.

\section{Discussion}

\section{Body composition}

The observation that resistance exercise in combination with a low carbohydrate diet resulted in reduced body weight and body fat as compared with similar exercise while on a regular diet is in accordance with previous studies showing a large loss of weight and body fat

Table 1 Anthropometric measures

\begin{tabular}{|c|c|c|c|c|c|c|}
\hline & \multicolumn{3}{|c|}{$(L c+E x)(n=8)$} & \multicolumn{3}{|c|}{$\operatorname{Ex}(n=8)$} \\
\hline & Baseline & Week 10 & Change & Baseline & Week 10 & Change \\
\hline Weight (kg) & $95.6 \pm 9.1^{*}$ & $90.0 \pm 8.8^{\dagger}$ & $-5.6 \pm 2.6^{* *}$ & $86.1 \pm 8.4$ & $87.0 \pm 7.9$ & $0.8 \pm 1.5$ \\
\hline LBM (kg) & $48.5 \pm 3.9^{*}$ & $48.5 \pm 3.9$ & $0.1 \pm 1.7$ & $43.3 \pm 3.5$ & $44.8 \pm 3.7^{\dagger}$ & $1.6 \pm 1.8$ \\
\hline Fat mass $(\mathrm{kg})$ & $44.0 \pm 8.6$ & $38.4 \pm 9.1^{\dagger}$ & $-5.6 \pm 2.9^{*}$ & $40.2 \pm 6.3$ & $39.5 \pm 6.6$ & $-0.6 \pm 0.8$ \\
\hline Fat $\%$ & $47.3 \pm 5.8$ & $43.7 \pm 7.0^{+}$ & $-3.6 \pm 2.5^{*}$ & $47.9 \pm 3.4$ & $46.7 \pm 4.2^{+}$ & $-1.3 \pm 1.3$ \\
\hline BMI & $32.9 \pm 4.5$ & $31.0 \pm 4.5^{\dagger}$ & $-1.9 \pm 0.8^{* *}$ & $31.7 \pm 4.2$ & $32.0 \pm 4.0$ & $0.3 \pm 0.5$ \\
\hline
\end{tabular}

Mean values \pm SD. ${ }^{*} p \leq 0.05$ vs Ex. ${ }^{* *} p \leq 0.001$ vs Ex. ${ }^{\dagger}$ Significant change from baseline $p \leq 0.05$. 


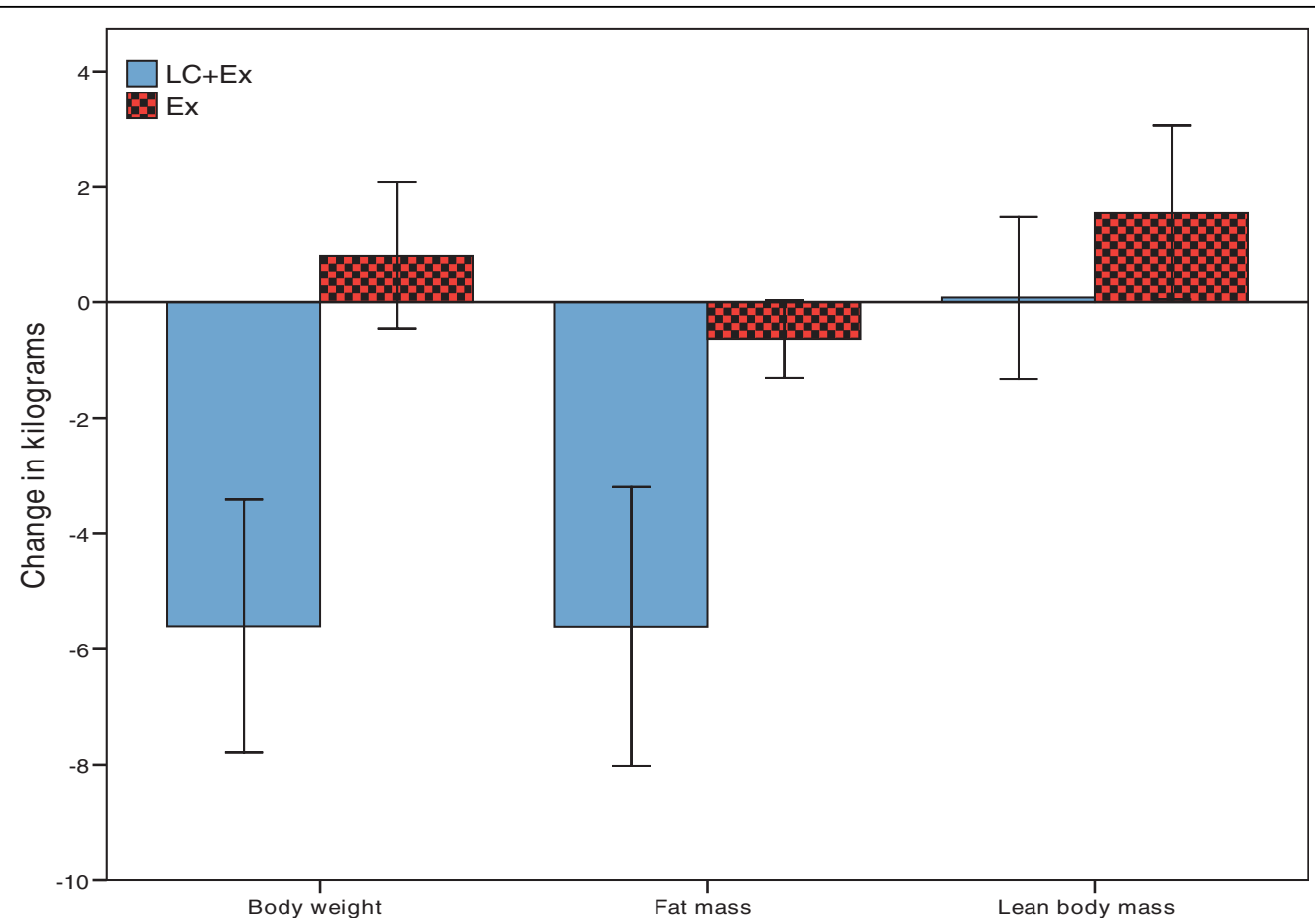

Figure 1 Effect of resistance exercise in combination with a regular diet (Ex) or resistance exercise in combination with a ketogenic diet (LC+Ex). Group changes from baseline in body weight and composition. Error bars indicate 95\% confidence interval.

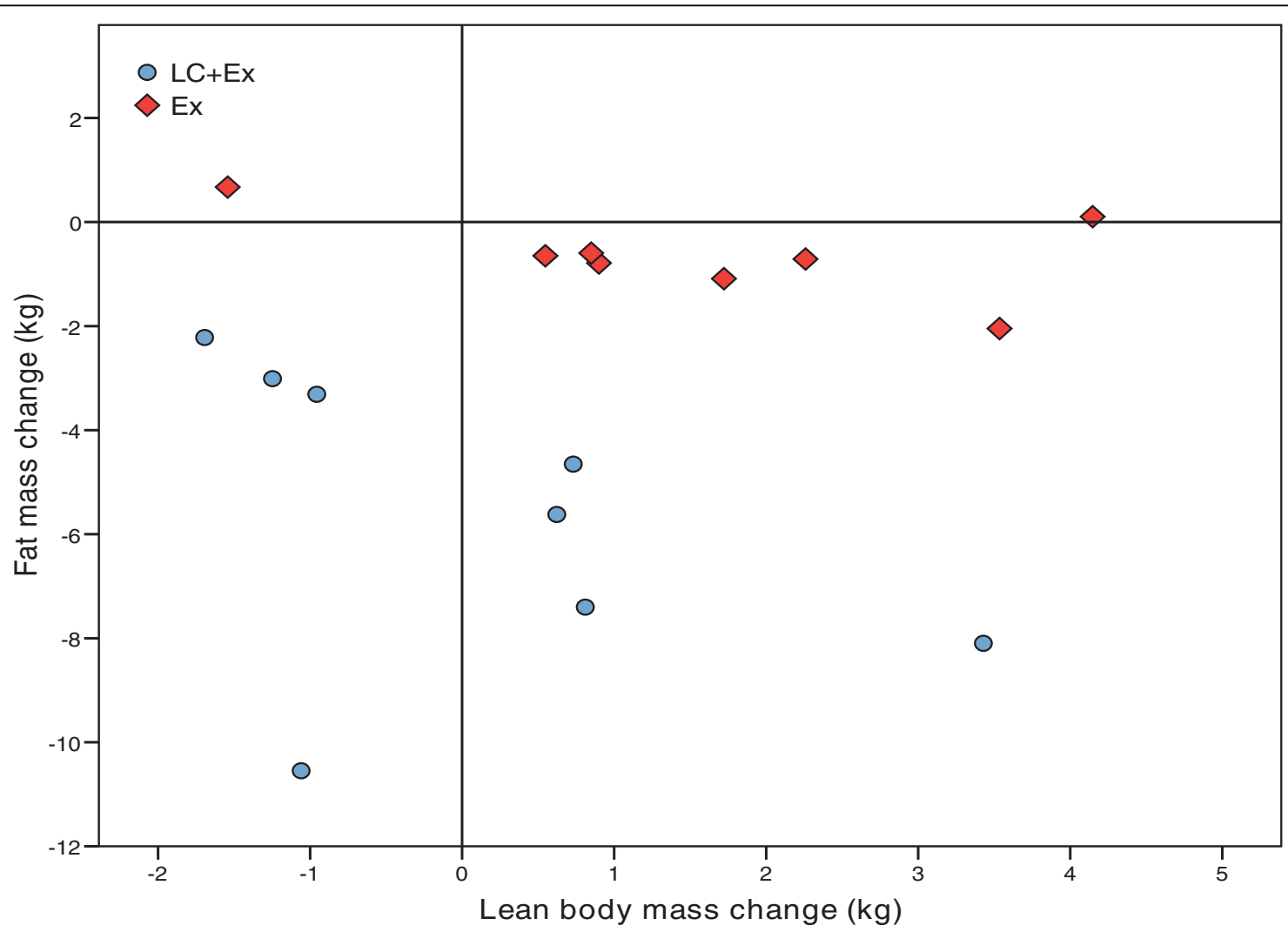

Figure 2 Effect of resistance exercise in combination with a regular diet (Ex) or resistance exercise in combination with a ketogenic diet (LC+Ex). Individual changes in body fat mass and lean body mass. 
Table 2 Dietary intake from two $4 \mathrm{~d}$ food records

\begin{tabular}{lll}
\hline NUTRIENT & $($ Lc+Ex) $(\mathbf{n}=\mathbf{8})$ & Ex $(\mathbf{n}=\mathbf{8})$ \\
\hline Energy (kJ) & $7349 \pm 1438$ & $8260 \pm 1684$ \\
Fat (g) & $131 \pm 27^{*}$ & $76 \pm 18$ \\
Fat (\% of energy) & $66 \pm 5^{*}$ & $34 \pm 3$ \\
Carbohydrate (g) & $23 \pm 10^{*}$ & $196 \pm 35$ \\
Carbohydrate (\% of energy) & $6 \pm 3^{*}$ & $41 \pm 4$ \\
Protein (g) & $95 \pm 26$ & $79 \pm 11$ \\
Protein (\% of energy) & $22 \pm 4^{*}$ & $17 \pm 2$ \\
Dietary fiber (g) & $12 \pm 6^{*}$ & $20 \pm 5$ \\
Alcohol (\% of energy) & $5 \pm 5$ & $7 \pm 6$ \\
\hline
\end{tabular}

Mean values \pm SD. ${ }^{*} p \leq 0.05$ vs Ex.

when carbohydrate intake is reduced and maintained at a low level [34-37,42-48].

This study do not clarify whether the observed results can be attributed to energy restriction in general or to carbohydrate restriction per se. Whatever the mechanisms might be, the subjects in the Lc+Ex group reduced body fat while maintaining lean body mass. Similar results have also been obtained using resistance exercise in combination with a regular energy restricted diet [27]. However, a decreased feeling of hunger seems to be an advantage with the low carbohydrate diet [49-51], an effect attributed to increased levels of ketone bodies [50], reduced levels of neuropeptide $\mathrm{Y}$ and leptin levels and decreased insulin levels [1]. Carbohydrate restriction will reduce glucose availability and lower insulin output, and may increase the concentration of counter regulatory hormones such as catecholamines and glucagon, thereby promoting adipose tissue lipolysis [52] and a shift in metabolism from fat storage to fatty acid release and oxidation [1]. In support of this, Volek et al [22] reported that serum insulin levels were inversely related to loss of body fat in a 6 week carbohydrate restricted diet trial, and approximately $70 \%$ of the variability in fat loss was accounted for by lower serum insulin levels.

Theoretically, carbohydrate driven de novo synthesis of fatty acids in the liver should be reduced by carbohydrate restriction, thereby resulting in reduced hepatic formation of TAG and very low density lipoproteins, with ensuing reduced uptake and esterification in adipose tissue [53]. Also, decreased glucose driven formation of glycerol-3-phosphate in the fat cell should reduce adipose tissue TAG production and storage [15]. Our findings seem to support this line of reasoning since there was a significant loss of adipose tissue mass in subjects ingesting the low carbohydrate diet.

In the Lc+ Ex group no increase in mean LBM could be detected in spite of the 10 weeks of resistance training. On the other hand, there was no loss of LBM in our study, unlike results from earlier weight loss studies [14]. Although low carbohydrate diets seem to reduce the amount of LBM lost with weight reduction [54], some reduction of LBM is still expected [9,34-37,47,55]. Maintenance of, or increase in LBM with resistance exercise has previously been demonstrated in females on calorie restricted diets $[26,27,56,57]$. The maintenance of LBM in the present trial may therefore presumably be attributed to the resistance training.

The mechanisms behind a lower increase in LBM when on a low carbohydrate diet compared to a diet higher in carbohydrate may in part be explained by a lower energy intake and lower insulin levels. In the Ex group in the present study, there was a significant positive correlation between carbohydrate intake and the increase in LBM. Unfortunately, we do not have data on insulin. Conceivably, a higher carbohydrate intake should give higher insulin levels and thereby stimulate anabolic processes like formation of glycogen, triacylglycerols and proteins [58] and reduce catabolic ones, e.g. lipolysis in fat tissue.

A second explanation for the lack of increased LBM in the Lc+Ex group may be the use of skeletal muscle protein for fuel. Dietary induced ketosis increases the use of amino acids for glucose production [59]. Although no correlation between protein intake and LBM change was found in our study, an association between low protein intake and lean body mass loss has been found in both low carbohydrate diets [14] as well as low calorie diets [18].

Fleck and Kraemer have summarized the findings of 29 studies measuring changes in lean body mass from resistance exercise in untrained individuals [60]. Average increase in LBM constituted $2 \mathrm{~kg}$ in 14 weeks, or 0.06

Table 3 Fasting blood glucose and serum lipids

\begin{tabular}{|c|c|c|c|c|c|c|c|c|}
\hline & \multicolumn{4}{|c|}{$(L c+E x)(n=8)$} & \multicolumn{4}{|c|}{ Ex $(n=8)$} \\
\hline & Baseline & Week 5 & Week 10 & Change pre-post & Baseline & Week 5 & Week 10 & Change pre-post \\
\hline Glucose $(\mathrm{mmol} / \mathrm{l})$ & $4.9 \pm 0.3$ & $5.4 \pm 0.9$ & $5.0 \pm 0.3$ & $0.1 \pm 0.3$ & $5.0 \pm 0.3$ & $4.9 \pm 0.5$ & $5.1 \pm 0.5$ & $0.1 \pm 0.4$ \\
\hline Total-C (mmol/l) & $5.6 \pm 1.1$ & $5.8 \pm 1.4$ & $5.7 \pm 1.2$ & $0.1 \pm 1.0$ & $5.0 \pm 0.7$ & $5.0 \pm 0.8$ & $4.8 \pm 0.7$ & $-0.2 \pm 0.6$ \\
\hline LDL-C (mmol/l) & $3.3 \pm 0.9$ & $3.6 \pm 1.2$ & $3.5 \pm 1.1$ & $0.2 \pm 0.9$ & $2.9 \pm 0.5$ & $2.9 \pm 0.6$ & $2.7 \pm 0.6$ & $-0.1 \pm 0.4$ \\
\hline $\mathrm{HDL}-\mathrm{C}(\mathrm{mmol} / \mathrm{l})$ & $1.6 \pm 0.5$ & $1.5 \pm 0.4$ & $1.5 \pm 0.4$ & $-0.1 \pm 0.2$ & $1.4 \pm 0.2$ & $1.4 \pm 0.2$ & $1.4 \pm 0.2$ & $0.1 \pm 0.2$ \\
\hline TAG $(\mathrm{mmol} / \mathrm{l})$ & $1.2 \pm 0.8$ & $1.0 \pm 0.3^{*}$ & $0.9 \pm 0.3^{*}$ & $-0.3 \pm 0.6$ & $1.4 \pm 0.5$ & $1.4 \pm 0.4$ & $1.3 \pm 0.4$ & $-0.1 \pm 0.3$ \\
\hline
\end{tabular}

Mean values \pm SD. ${ }^{*} p \leq 0.05$ vs Ex. 
$\mathrm{kg}$ of LBM per exercise session. In the studies using only female participants the equivalent number was $0.04 \mathrm{~kg}$ LBM increase per session. Our Ex group experienced an average LBM increase of $1.55 \mathrm{~kg}$ in 10 weeks or $0.08 \mathrm{~kg}$ per exercise session, which is in accordance with, although somewhat higher, than previously reported.

Exercise is in itself a valuable addition to weight loss diets. Meckling and Sherfey showed an added effect of exercise in inducing weight loss with both a low carbohydrate and a high carbohydrate diet. Best results on weight loss were achieved using a combination of exercise and a high protein, low carbohydrate diet [61], thus confirming the findings of Layman et al [62] who also showed that a diet with higher protein and reduced carbohydrate content combined with exercise additively improved body composition during weight loss. On the basis of these studies it seems that carbohydrate restriction in combination with exercise and resistance exercise in particular, offers an advantage over both low fat diets with exercise and low carbohydrate diets without exercise, in improving body composition.

Although there were large individual differences in body composition changes in our study, several subjects experienced very large changes in body composition in a short time period. If the details surrounding the individual differences in response to a combination of carbohydrate restriction and resistance exercise can be more clearly understood, this strategy may prove to be of great importance in the management of overweight and obesity. Also, a change in body composition may be more favorable than weight loss. Resistance exercise is in itself effective for improving body composition and is thus of importance for the treatment of obesity and its related metabolic disorders. It is, however, difficult to quantify the need for muscle mass retention. A small decrease in total muscle mass may not necessarily be considered negative. Obese individuals often have a larger total LBM than leaner counterparts. Loss of body weight will also reduce the load on the musculoskeletal system. With regard to muscle functionality and metabolic role, the quality of muscles may be considered more important than size.

\section{Performance}

The attendance at the exercise sessions did not differ between the two groups. In addition the instructors did not observe any group differences in exercise intensity or the ability to perform at the requested loads. We therefore find it less likely that differences in exercise intensity would account for the between group differences in LBM change.

Low carbohydrate diets may result in decreased anaerobic performance $[39,63]$, but several studies have observed no decrements in aerobic exercise with carbohydrate restricted diets [64]. Indeed, sustained aerobic performance might be beneficially influenced by a high fat diet [65-67]. White et al found a positive correlation between rating of perceived exertion and blood ketones [68]. In contrast, Brinkworth et al [37] recently observed no correlation between blood ketones and ratings of perceived exertion in their 8 week study, and observed no detrimental effects on maximal or submaximal markers of aerobic exercise or muscle strength, compared to an isocaloric high carbohydrate diet.

Unfortunately, performance ability was not measured objectively in the present study, and the possibility of reduced performance with carbohydrate restriction cannot be excluded.

\section{Blood lipids and glucose}

As there were no significant effects on fasting serum lipids in subjects performing resistance exercise while on a ketogenic diet, and since carbohydrate restriction generally seem to improve the fasting lipid profiles [5], we would not expect harmful long term effects of the current regime on the fasting concentration of the measured blood lipids. It should be kept in mind, however, that the 24 hour serum lipid load may increase in subjects ingesting a high fat diet in spite of lower fasting levels, since the fasting concentration of TAG is the lowest value during the day on a high fat diet, while it is the highest one on high carbohydrate diet [69]. On the other hand, carbohydrate restriction may lower both fasting and non-fasting serum triglycerides [70] and studies of postprandial lipemia have shown a strong correlation between postprandial triglyceride levels and the level of fasting triglycerides [71]. Additionally, it is well known that the concentration of plasma free fatty acids (FFA) increases on a ketogenic diet [72], and high FFA levels may be an important cardiovascular risk factor [73], especially if sustained. However, plasma FFA levels were not determined in the present trial. In any instance, we consider the exercise part of the present trial to have positive health effects. Both resistance exercise [25] and aerobic exercise [74] have been associated with improvements in CVD risk factors. Previous studies of resistance exercise have demonstrated positive effects on blood lipids [25] which may in part be explained by improved insulin sensitivity, and an increase in skeletal muscle lipoprotein lipase activity, resulting in increased VLDL-triacylglycerol catabolism [75].

\section{Limitations}

This is a small study in which only some variables were determined. Habitual dietary intake was not assessed. To be more complete the study should have included determination of insulin levels and sensitivity, as well as albumin bound fatty acids, plasma lipoprotein distribution and fatty acid distribution. In addition, only fasting 
values of blood variables were determined and the effect of our trial on many CVD risk factors is thus unknown. We also did not account for or make any evaluation of sex or thyroid hormones, catecholamines, glucagon, corticosteroids, all of which known to be metabolic regulators [76-79]. Menstrual cycle phase is known to influence serum lipoproteins [80]. Menstrual cycle was not coordinated with blood collection.

\section{Conclusions}

Although this study was not designed to fully elucidate the mechanisms behind the observed body composition changes, the study has shown that resistance exercise performed twice weekly in overweight women on a low carbohydrate ketogenic may reduce body fat without significantly changing LBM, while resistance exercise on a regular diet may increase LBM in without significantly affecting fat mass. Fasting blood lipids do not seem to be negatively influenced by the combination of a low carbohydrate diet and resistance exercise.

\section{List of abbreviations}

LBM: Lean body mass; DEXA: Dual - Energy $X$ - ray Absorptiometry; TAG: Triacylglycerol; Tot-C: Total cholesterol; HDL-C: High density lipoprotein cholesterol; LDL-C: Low density lipoprotein cholesterol; CVD: Cardiovascular disease.

\section{Acknowledgements}

This study received material including a book describing a commercial ketogenic diet, urine reagent strips, and vitamin/mineral supplements from Ketolyse AS. Investigators at the Norwegian School of Sport Science conducted the study in its entirety and maintained exclusive control of all data and analyses. The funding source had no involvement in any part of the recruitment of participants, study intervention, data collection, data analyses, interpretation of the data, or preparation or review of this manuscript. We acknowledge Sindre Lee for his important contribution as training instructor.

\section{Author details}

'Department of Sport Medicine, Norwegian School of Sport Sciences, Sognsveien 220, Oslo, Norway. ${ }^{2}$ Section of Preventive Medicine and Epidemiology, University of Oslo, Norway. ${ }^{3}$ Department of Physical Performance, Norwegian School of Sport Sciences, Sognsveien 220, Oslo, Norway.

\section{Authors' contributions}

PTJ and IAM designed the study and organized and analyzed the data. ATH and SET provided critical statistical and methodical advice. PTJ, ATH, SET and HDM wrote the manuscript. HDM was in charge of medical safety and interpretation of blood sample values. All authors read and approved the final manuscript.

\section{Competing interests}

The authors declare that they have no competing interests.

Received: 25 November 2009 Accepted: 2 March 2010 Published: 2 March 2010

\section{References}

1. Westman EC, Feinman RD, Mavropoulos JC, Vernon MC, Volek JS, Wortman JA, Yancy WS, Phinney SD: Low-carbohydrate nutrition and metabolism. Am J Clin Nutr 2007, 86:276-284.
2. Feinman RD, Volek JS: Low carbohydrate diets improve atherogenic dyslipidemia even in the absence of weight loss. Nutr Metab (Lond) 2006, $3: 24$.

3. Volek JS, Feinman RD: Carbohydrate restriction improves the features of Metabolic Syndrome. Metabolic Syndrome may be defined by the response to carbohydrate restriction. Nutr Metab (Lond) 2005, 2:31.

4. Hession M, Rolland C, Kulkarni U, Wise A, Broom J: Systematic review of randomized controlled trials of low-carbohydrate vs. low-fat/low-calorie diets in the management of obesity and its comorbidities. Obes Rev 2009, 10:36-50

5. Accurso A, Bernstein RK, Dahlqvist A, Draznin B, Feinman RD, Fine EJ, Gleed A, Jacobs DB, Larson G, Lustig RH, Manninen AH, McFarlane SI, Morrison K, Nielsen JV, Ravnskov U, Roth KS, Silvestre R, Sowers JR, Sundberg R, Volek JS, Westman EC, Wood RJ, Wortman J, Vernon MC: Dietary carbohydrate restriction in type 2 diabetes mellitus and metabolic syndrome: time for a critical appraisal. Nutr Metab (Lond) 2008, $5: 9$

6. Volek JS, Fernandez ML, Feinman RD, Phinney SD: Dietary carbohydrate restriction induces a unique metabolic state positively affecting atherogenic dyslipidemia, fatty acid partitioning, and metabolic syndrome. Prog Lipid Res 2008, 47:307-318.

7. Nordmann AJ, Nordmann A, Briel M, Keller U, Yancy WS Jr, Brehm BJ, Bucher HC: Effects of low-carbohydrate vs low-fat diets on weight loss and cardiovascular risk factors: a meta-analysis of randomized controlled trials. Arch Intern Med 2006, 166:285-293.

8. Dashti HM, Al Zaid NS, Mathew TC, Al Mousawi M, Talib H, Asfar SK, Behbahani Al: Long term effects of ketogenic diet in obese subjects with high cholesterol level. Mol Cell Biochem 2006, 286:1-9.

9. Noakes M, Foster PR, Keogh JB, James AP, Mamo JC, Clifton PM: Comparison of isocaloric very low carbohydrate/high saturated fat and high carbohydrate/low saturated fat diets on body composition and cardiovascular risk. Nutr Metab (Lond) 2006, 3:7.

10. Shai I, Schwarzfuchs D, Henkin Y, Shahar DR, Witkow S, Greenberg I, Golan R, Fraser D, Bolotin A, Vardi H, Tangi-Rozental O, Zuk-Ramot R, Sarusi B, Brickner D, Schwartz Z, Sheiner E, Marko R, Katorza E, Thiery J, Fiedler GM, Bluher M, Stumvoll M, Stampfer MJ: Weight loss with a lowcarbohydrate, Mediterranean, or low-fat diet. N Engl J Med 2008, 359:229-241.

11. Gardner CD, Kiazand A, Alhassan S, Kim S, Stafford RS, Balise RR, Kraemer HC, King AC: Comparison of the Atkins, Zone, Ornish, and LEARN diets for change in weight and related risk factors among overweight premenopausal women: the A TO Z Weight Loss Study: a randomized trial. JAMA 2007, 297:969-977.

12. Sacks FM, Bray GA, Carey VJ, Smith SR, Ryan DH, Anton SD, McManus K, Champagne CM, Bishop LM, Laranjo N, Leboff MS, Rood JC, de Jonge L, Greenway FL, Loria CM, Obarzanek E, Williamson DA: Comparison of weight-loss diets with different compositions of fat, protein, and carbohydrates. N Engl J Med 2009, 360:859-873.

13. Fine EJ, Feinman RD: Thermodynamics of weight loss diets. Nutr Metab (Lond) 2004, 1:15.

14. Krieger JW, Sitren HS, Daniels MJ, Langkamp-Henken B: Effects of variation in protein and carbohydrate intake on body mass and composition during energy restriction: a meta-regression 1. Am J Clin Nutr 2006, 83:260-274.

15. Feinman RD, Fine EJ: Nonequilibrium thermodynamics and energy efficiency in weight loss diets. Theor Biol Med Model 2007, 4:27.

16. Redman LM, Heilbronn LK, Martin CK, Alfonso A, Smith SR, Ravussin E: Effect of calorie restriction with or without exercise on body composition and fat distribution. J Clin Endocrinol Metab 2007, 92:865-872.

17. Ross R, Dagnone D, Jones PJ, Smith H, Paddags A, Hudson R, Janssen I: Reduction in obesity and related comorbid conditions after diet-induced weight loss or exercise-induced weight loss in men. A randomized, controlled trial. Ann Intern Med 2000, 133:92-103.

18. Bopp MJ, Houston DK, Lenchik L, Easter L, Kritchevsky SB, Nicklas BJ: Lean mass loss is associated with low protein intake during dietary-induced weight loss in postmenopausal women. J Am Diet Assoc 2008, 108:1216-1220.

19. Chaston TB, Dixon JB, O'Brien PE: Changes in fat-free mass during significant weight loss: a systematic review. Int J Obes (Lond) 2007, 31:743-750. 
20. Volek JS, Gomez AL, Love DM, Weyers AM, Hesslink R Jr, Wise JA, Kraemer WJ: Effects of an 8-week weight-loss program on cardiovascular disease risk factors and regional body composition. Eur J Clin Nutr 2002, 56:585-592.

21. Willi SM, Oexmann MJ, Wright NM, Collop NA, Key LL Jr: The effects of a high-protein, low-fat, ketogenic diet on adolescents with morbid obesity: body composition, blood chemistries, and sleep abnormalities. Pediatrics 1998, 101:61-67.

22. Volek JS, Sharman MJ, Love DM, Avery NG, Gomez AL, Scheett TP, Kraemer WJ: Body composition and hormonal responses to a carbohydrate-restricted diet. Metabolism 2002, 51:864-870.

23. Young CM, Scanlan SS, Im HS, Lutwak L: Effect of body composition and other parameters in obese young men of carbohydrate level of reduction diet. Am J Clin Nutr 1971, 24:290-296.

24. Zatsiorsky VM: Science and practice of strength training Champaign, IL: Human Kinetics 2006.

25. Donnelly JE, Blair SN, Jakicic JM, Manore MM, Rankin JW, Smith BK: American College of Sports Medicine Position Stand. Appropriate physical activity intervention strategies for weight loss and prevention of weight regain for adults. Med Sci Sports Exerc 2009, 41:459-471.

26. Ross R, Pedwell H, Rissanen J: Response of total and regional lean tissue and skeletal muscle to a program of energy restriction and resistance exercise. Int J Obes Relat Metab Disord 1995, 19:781-787.

27. Ballor DL, Katch $\mathrm{VL}$, Becque MD, Marks CR: Resistance weight training during caloric restriction enhances lean body weight maintenance. Am J Clin Nutr 1988, 47:19-25.

28. Koopman R, van Loon L: Aging, exercise, and muscle protein metabolism. J Appl Physiol 2009, 106:2040-2048.

29. Bouchard DR, Soucy L, Senechal M, Dionne IJ, Brochu M: Impact of resistance training with or without caloric restriction on physical capacity in obese older women. Menopause 2009, 16:66-72.

30. Castaneda C, Layne JE, Munoz-Orians L, Gordon PL, Walsmith J, Foldvari M, Roubenoff R, Tucker KL, Nelson ME: A randomized controlled trial of resistance exercise training to improve glycemic control in older adults with type 2 diabetes. Diabetes Care 2002, 25:2335-2341.

31. Thomas DE, Elliott EJ, Naughton GA: Exercise for type 2 diabetes mellitus. Cochrane Database Syst Rev 2006, 3:CD002968.

32. Sigal RJ, Kenny GP, Boule NG, Wells GA, Prud'homme D, Fortier M, Reid RD, Tulloch $\mathrm{H}$, Coyle D, Phillips P, Jennings A, Jaffey J: Effects of aerobic training, resistance training, or both on glycemic control in type 2 diabetes: a randomized trial. Ann Intern Med 2007, 147:357-369.

33. Stiegler $P$, Cunliffe $A$ : The role of diet and exercise for the maintenance of fat-free mass and resting metabolic rate during weight loss. Sports Med 2006, 36:239-262.

34. Yancy WS Jr, Olsen MK, Guyton JR, Bakst RP, Westman EC: A lowcarbohydrate, ketogenic diet versus a low-fat diet to treat obesity and hyperlipidemia: a randomized, controlled trial. Ann Intern Med 2004, 140:769-777.

35. Brehm BJ, Seeley RJ, Daniels SR, D'Alessio DA: A randomized trial comparing a very low carbohydrate diet and a calorie-restricted low fat diet on body weight and cardiovascular risk factors in healthy women. J Clin Endocrinol Metab 2003, 88:1617-1623.

36. Volek JS, Phinney SD, Forsythe CE, Quann EE, Wood RJ, Puglisi MJ, Kraemer WJ, Bibus DM, Fernandez ML, Feinman RD: Carbohydrate restriction has a more favorable impact on the metabolic syndrome than a low fat diet. Lipids 2009, 44:297-309.

37. Brinkworth GD, Noakes M, Clifton PM, Buckley JD: Effects of a low carbohydrate weight loss diet on exercise capacity and tolerance in obese subjects. Obesity (Silver Spring) 2009, 17:1916-1923.

38. Gardner CD, Kiazand A, Alhassan S, Kim S, Stafford RS, Balise RR, Kraemer HC, King AC: Comparison of the Atkins, Zone, Ornish, and LEARN diets for change in weight and related risk factors among overweight premenopausal women: the A TO Z Weight Loss Study: a randomized trial. JAMA 2007, 297:969-977.

39. Phinney SD: Ketogenic diets and physical performance. Nutr Metab (Lond) 2004, 1:2.

40. Andersen TP: Slank med ketolysekuren: en enklere vei til et lettere liv Oslo: Gyldendal fakta 2005.

41. The Norwegian Food Safety Authority, Norwegian Directorate for Health, The Department of Nutrition UoO. Norwegian Food Composition Tables. 2006 [http://matportalen.no/matvaretabellen].
42. Foster GD, Wyatt HR, Hill JO, McGuckin BG, Brill C, Mohammed BS, Szapary PO, Rader DJ, Edman JS, Klein S: A randomized trial of a lowcarbohydrate diet for obesity. N Engl J Med 2003, 348:2082-2090.

43. Sondike SB, Copperman N, Jacobson MS: Effects of a low-carbohydrate diet on weight loss and cardiovascular risk factor in overweight adolescents. J Pediatr 2003, 142:253-258.

44. Samaha FF, lqbal N, Seshadri P, Chicano KL, Daily DA, McGrory J, Williams T, Williams M, Gracely EJ, Stern L: A low-carbohydrate as compared with a low-fat diet in severe obesity. N Engl J Med 2003, 348:2074-2081.

45. Dansinger ML, Gleason JA, Griffith JL, Selker HP, Schaefer EJ: Comparison of the Atkins, Ornish, Weight Watchers, and Zone diets for weight loss and heart disease risk reduction: a randomized trial. JAMA 2005, 293:43-53.

46. Halyburton AK, Brinkworth GD, Wilson CJ, Noakes M, Buckley JD, Keogh JB, Clifton PM: Low- and high-carbohydrate weight-loss diets have similar effects on mood but not cognitive performance. Am J Clin Nutr 2007, 86:580-587.

47. Keogh JB, Brinkworth GD, Noakes M, Belobrajdic DP, Buckley JD, Clifton PM: Effects of weight loss from a very-low-carbohydrate diet on endothelial function and markers of cardiovascular disease risk in subjects with abdominal obesity. Am J Clin Nutr 2008, 87:567-576.

48. Gardner CD, Kiazand A, Alhassan S, Kim S, Stafford RS, Balise RR, Kraemer HC, King AC: Comparison of the Atkins, Zone, Ornish, and LEARN diets for change in weight and related risk factors among overweight premenopausal women: the A TO Z Weight Loss Study: a randomized trial. JAMA 2007, 297:969-977.

49. Boden G, Sargrad K, Homko C, Mozzoli M, Stein TP: Effect of a lowcarbohydrate diet on appetite, blood glucose levels, and insulin resistance in obese patients with type 2 diabetes. Ann Intern Med 2005, 142:403-411.

50. Johnstone AM, Horgan GW, Murison SD, Bremner DM, Lobley GE: Effects of a high-protein ketogenic diet on hunger, appetite, and weight loss in obese men feeding ad libitum. Am J Clin Nutr 2008, 87:44-55.

51. McClernon FJ, Yancy WS Jr, Eberstein JA, Atkins RC, Westman EC: The effects of a low-carbohydrate ketogenic diet and a low-fat diet on mood, hunger, and other self-reported symptoms. Obesity (Silver Spring) 2007, 15:182-187.

52. Volek JS, Sharman MJ: Cardiovascular and hormonal aspects of very-lowcarbohydrate ketogenic diets. Obes Res 2004, 12(Suppl 2):115S-123S.

53. Schwarz JM, Linfoot P, Dare D, Aghajanian K: Hepatic de novo lipogenesis in normoinsulinemic and hyperinsulinemic subjects consuming high-fat, low-carbohydrate and low-fat, high-carbohydrate isoenergetic diets. Am J Clin Nutr 2003, 77:43-50.

54. Manninen $\mathrm{AH}$ : Very-low-carbohydrate diets and preservation of muscle mass. Nutr Metab (Lond) 2006, 3:9.

55. Meckling KA, O'Sullivan C, Saari D: Comparison of a low-fat diet to a lowcarbohydrate diet on weight loss, body composition, and risk factors for diabetes and cardiovascular disease in free-living, overweight men and women. J Clin Endocrinol Metab 2004, 89:2717-2723.

56. Geliebter A, Maher MM, Gerace L, Gutin B, Heymsfield SB, Hashim SA: Effects of strength or aerobic training on body composition, resting metabolic rate, and peak oxygen consumption in obese dieting subjects. Am J Clin Nutr 1997, 66:557-563.

57. Janssen I, Ross R: Effects of sex on the change in visceral, subcutaneous adipose tissue and skeletal muscle in response to weight loss. Int J Obes Relat Metab Disord 1999, 23:1035-1046.

58. Tipton KD, Wolfe RR: Exercise, protein metabolism, and muscle growth. Int J Sport Nutr Exerc Metab 2001, 11:109-132.

59. Browning JD, Weis B, Davis J, Satapati S, Merritt M, Malloy CR, Burgess SC: Alterations in hepatic glucose and energy metabolism as a result of calorie and carbohydrate restriction. Hepatology 2008, 48:1487-1496.

60. Fleck SJ, Kraemer WJ: Designing resistance training programs Champaign, IL: Human Kinetics 2004.

61. Meckling KA, Sherfey R: A randomized trial of a hypocaloric high-protein diet, with and without exercise, on weight loss, fitness, and markers of the Metabolic Syndrome in overweight and obese women. Appl Physiol Nutr Metab 2007, 32:743-752.

62. Layman DK, Evans E, Baum Jl, Seyler J, Erickson DJ, Boileau RA: Dietary protein and exercise have additive effects on body composition during weight loss in adult women. J Nutr 2005, 135:1903-1910.

63. Fleming J, Sharman MJ, Avery NG, Love DM, Gomez AL, Scheett TP, Kraemer WJ, Volek JS: Endurance capacity and high-intensity exercise 
performance responses to a high fat diet. Int I Sport Nutr Exerc Metab 2003, 13:466-478.

64. Erlenbusch M, Haub M, Munoz K, MacConnie S, Stillwell B: Effect of highfat or high-carbohydrate diets on endurance exercise: a meta-analysis. Int I Sport Nutr Exerc Metab 2005, 15:1-14.

65. Lambert EV, Speechly DP, Dennis SC, Noakes TD: Enhanced endurance in trained cyclists during moderate intensity exercise following 2 weeks adaptation to a high fat diet. Eur J Appl Physiol Occup Physiol 1994, 69:287-293.

66. Rowlands DS, Hopkins WG: Effects of high-fat and high-carbohydrate diets on metabolism and performance in cycling. Metabolism 2002, 51:678-690.

67. Muoio DM, Leddy JJ, Horvath PJ, Awad AB, Pendergast DR: Effect of dietary fat on metabolic adjustments to maximal VO2 and endurance in runners. Med Sci Sports Exerc 1994, 26:81-88.

68. White AM, Johnston CS, Swan PD, Tjonn SL, Sears B: Blood ketones are directly related to fatigue and perceived effort during exercise in overweight adults adhering to low-carbohydrate diets for weight loss: a pilot study. J Am Diet Assoc 2007, 107:1792-1796.

69. Schlierf G, Reinheimer W, Stossberg V: Diurnal patterns of plasma triglycerides and free fatty acids in normal subjects and in patients with endogenous (type IV) hyperlipoproteinemia. Nutr Metab 1971, 13:80-91.

70. Sharman MJ, Kraemer WJ, Love DM, Avery NG, Gomez AL, Scheett TP, Volek JS: A ketogenic diet favorably affects serum biomarkers for cardiovascular disease in normal-weight men. J Nutr 2002, 132:1879-1885.

71. Schaefer EJ, Audelin MC, McNamara JR, Shah PK, Tayler T, Daly JA, Augustin $\mathrm{J}$, Seman $\sqcup$, Rubenstein $\mathrm{J}$ : Comparison of fasting and postprandial plasma lipoproteins in subjects with and without coronary heart disease. Am J Cardiol 2001, 88:1129-1133.

72. Volek JS, Sharman MJ, Forsythe CE: Modification of lipoproteins by very low-carbohydrate diets. J Nutr 2005, 135:1339-1342.

73. Pilz S, Scharnagl H, Tiran B, Seelhorst U, Wellnitz B, Boehm BO, Schaefer JR, Marz W: Free fatty acids are independently associated with all-cause and cardiovascular mortality in subjects with coronary artery disease. J Clin Endocrinol Metab 2006, 91:2542-2547.

74. Kelley GA, Kelley KS: Efficacy of aerobic exercise on coronary heart disease risk factors. Prev Cardiol 2008, 11:71-75.

75. Haskell WL: The influence of exercise on the concentrations of triglyceride and cholesterol in human plasma. Exerc Sport Sci Rev 1984 12:205-244.

76. Galletly C, Moran L, Noakes M, Clifton P, Tomlinson L, Norman R: Psychological benefits of a high-protein, low-carbohydrate diet in obese women with polycystic ovary syndrome-a pilot study. Appetite 2007, 49:590-593.

77. Mavropoulos JC, Yancy WS, Hepburn J, Westman EC: The effects of a lowcarbohydrate, ketogenic diet on the polycystic ovary syndrome: a pilot study. Nutr Metab (Lond) 2005, 2:35.

78. Roos A, Bakker SJ, Links TP, Gans RO, Wolffenbuttel BH: Thyroid function is associated with components of the metabolic syndrome in euthyroid subjects. J Clin Endocrinol Metab 2007, 92:491-496.

79. Amati F, Dube JJ, Stefanovic-Racic M, Toledo FG, Goodpaster BH: Improvements in insulin sensitivity are blunted by subclinical hypothyroidism. Med Sci Sports Exerc 2009, 41:265-269.

80. Barnett JB, Woods MN, Lamon-Fava S, Schaefer EJ, McNamara JR Spiegelman D, Hertzmark E, Goldin B, Longcope C, Gorbach SL: Plasma lipid and lipoprotein levels during the follicular and luteal phases of the menstrual cycle. J Clin Endocrinol Metab 2004, 89:776-782.

doi:10.1186/1743-7075-7-17

Cite this article as: Jabekk et al:: Resistance training in overweight women on a ketogenic diet conserved lean body mass while reducing body fat. Nutrition \& Metabolism 2010 7:17.

\section{Submit your next manuscript to BioMed Central and take full advantage of:}

- Convenient online submission

- Thorough peer review

- No space constraints or color figure charges

- Immediate publication on acceptance

- Inclusion in PubMed, CAS, Scopus and Google Scholar

- Research which is freely available for redistribution

Submit your manuscript at www.biomedcentral.com/submit
Biomed Central 